\title{
Anna Iwanicka-Maciura, Antropologia filozoficzna w ujęciu polskiej szkoły higieny psychicznej, Wydawnictwo Uniwersytetu Rzeszowskiego, Rzeszów 2015, ss. 221
}

DOI: http://dx.doi.org/10.12775/RF.2017.041

Nie tęsknij za równowaga prostacka!! Lepiej bądź niezrównoważony, zanim zdobędziesz swym świadomym wysiłkiem równowage na wyższym poziomie! Kazimierz Dąbrowski ${ }^{1}$

Monografia zatytułowana Antropologia filozoficzna w ujęciu polskiej szkoły higieny psychicznej wyszła spod pióra Anny Iwanickiej-Maciury, która z zawodu jest pielęgniarka, biologiem, a przede wszystkim doktorem nauk humanistycznych i adiunktem na Wydziale Medycznym Uniwersytetu Rzeszowskiego. Już na samym wstępie dostrzegalna jest interdyscyplinarność zainteresowań badawczych autorki, co przejawia się w publikacji będącej przedmiotem mojej analizy i refleksji.

Anna Iwanicka-Maciura podjęła się niezwykle żmudnej pracy zrekonstruowania, przeanalizowania, a następnie porównania światopoglądu myślicieli z różnych dziedzin nauki: filozofii, pedagogiki, psychologii i medycyny. Badaczy tych połączyła jedna i przede wszystkim zasadnicza wspólna cecha, a mianowicie afirmowanie higieny psychicznej, a co za tym idzie poszanowanie każdego indywidualnego człowieka, akceptacja odmienności, zwrócenie uwagi na moralną odpowiedzialność w odniesieniu do wszelkich zaburzeń psychicznych czy zmartwień egzystencjalnych. Zaskakująca, ale i zajmująca wydała mi się analiza wywiadu środowiskowego, przeprowadzonego w Domu Pomocy Społecznej dla Osób Chorych Psychicznie i Niepełnosprawnych Umysłowo w Jarosławiu, którą autorka zamieściła na zakończenie swo-

1 A. Iwanicka-Maciura, Antropologia filozoficzna w ujęciu polskiej szkoły higieny psychicznej, Wydawnictwo Uniwersytetu Rzeszowskiego, Rzeszów 2015, s. 208. 
jej pracy w formie aneksu. Anna Iwanicka-Maciura załączyła również Kartę Zdrowia Psychicznego autorstwa Kazimierza Dąbrowskiego, która określa zasady i zadania higieny psychicznej².

Monografia składa się z sześciu rozdziałów, przedstawionych chronologicznie: Polska szkoła higieny psychicznej, Filozofia zdrowia psychicznego, Człowiek w ujęciu twórców polskiej szkoły higieny psychicznej, Poglady polskich myślicieli nawiazujacych do higieny psychicznej, Wartości indywidualne postulowane na gruncie higieny psychicznej, Wartości społeczne i polityczne sformułowane na gruncie higieny psychicznej. Najbardziej interesujące wydają się rozważania i zgłębienie fenomenu filozofii zdrowia, który stanowi wykładnię światopoglądową takich uczonych, jak: Kazimierz Dąbrowski ${ }^{3}$, Maria Grzegorzewska ${ }^{4}$, Maria Grzywak-Kaczyńska5,

2 Ibidem, s. 220.

3 Kazimierz Dąbrowski (1902-1980) stworzył w Polsce koncepcję higieny psychicznej oraz dezintegracji pozytywnej. Był pomysłodawcą utworzenia takich organizacji, jak: Instytut Higieny Psychicznej, działający w latach 1935-1949, Wyższa Szkoła Higieny Psychicznej w Warszawie, działająca w latach 1945-1953, Sanatorium Neuropsychiatrii Dziecięcej w Zagórzu, które powstało w 1939 roku, Ośrodek Higieny Psychicznej dla Ludzi Zdrowych, funkcjonujący w latach 1977-1980. Najważniejsze dzieła Dąbrowskiego to: Zdrowie psychiczne, Państwowe Wydawnictwo Naukowe, Warszawa 1985; Dezintegracja pozytywna, Państwowy Instytut Wydawniczy, Warszawa 1977; Co to jest higiena psychiczna, Nasza Księgarnia, Warszawa 1962.

4 Maria Grzegorzewska (1888-1967), założycielka Instytutu Nauczycielskiego i Pedagogiki Specjalnej w Polsce. Była redaktorem czasopisma „Szkoła Specjalna”. Główne dzieła: Studium na temat rozwoju uczuć estetycznych: badania z zakresu estetyki eksperymentalnej prowadzone wśród uczniów szkót brukselskich, przeł. Halina Lubicz-Trawkowska, [red. Monika Bielska-Łach, Hanna Cieśla], Wydawnictwo Akademii Pedagogiki Specjalnej, Warszawa 2012; Listy do młodego nauczyciela: cykl I - III, Wyższa Szkoła Pedagogiki Specjalnej im. Marii Grzegorzewskiej, Warszawa 1996; Pedagogika specjalna: skrypt wykładów, Państwowy Instytut Pedagogiki Specjalnej, Warszawa 1968.

5 Maria Grzywak-Kaczyńska (1886-1979), zasłużony polski psycholog. W czasie okupacji wojennej pracowała w Studium Higieny Psychicznej i Psychologii Stosowanej w Zagórzu pod Warszawa pracowała również w Instytucie Higieny Psychicznej. W latach powojennych pracowała w Katolickim Uniwersytecie Lubelskim. Była kierownikiem Katedry Psychologii Eksperymentalnej. Współredaktor czasopism naukowych: „Problemy Psychoterapii Dzieci i Młodzieży” i „Zdrowie Psychiczne”. Zob. A. Iwanicka-Maciura, Antropologia filozoficzna w ujęciu polskiej szkoły higieny psychicznej, Wydawnictwo Uniwersytetu Rzeszowskiego, Rzeszów 2015, s. 61. Główne dzieła Grzywak-Kaczyńskiej: Erotyka w aspekcie zdrowia psychicznego: praca zbiorowa, Instytut Wydawniczy Pax, Warszawa 1985; Psychologia dla każdego, Instytut Wydawniczy PAX, Warszawa 1975; Zdolność do uczuć wyższych a prawidłowy rozwój psychiczny, Państwowy Instytut Higieny Psychicznej, Warszawa 1947. 
Julian Aleksandrowicz ${ }^{6}$, Stefan Baley ${ }^{7}$, Andrzej Szyszko-Bohusz, Tadeusz Kielanowski ${ }^{9}$, Antonii Kępiński ${ }^{10}$, Włodzimierz Sedlak ${ }^{11}$, Henryk Skolimowski ${ }^{12}$, Jerzy Grotowski ${ }^{13}$.

Zaprezentowani pokrótce przeze mnie myśliciele w sposób jednoznaczny odnosili się do zdrowia psychicznego, gdyż traktowali je holistycznie i wielopłaszczyznowo. Kępiński krytykował osobowość psychopatyczna, tzw. ludzi silny ch, którzy przejawiają skłonności do konformizmu, despocji, zachowań egoistycznych i autorytarnych. W po-

${ }^{6}$ Julian Aleksandrowicz (1908-1988) ukończył studia medyczne na Uniwersytecie Jagiellońskim. Profesor krakowskiej Akademii Medycznej i kierownik III Kliniki Chorób Wewnętrznych, następnie prowadził Klinikę Hematologiczną. Zajmował się ekologiczną profilaktyką białaczek i chorobami cywilizacyjnymi. Główne dzieła: Kartki z dziennika doktora Twardego, Wydawnictwo Literackie, Kraków 2001; Sumienie ekologiczne, "Wiedza Powszechna”, Warszawa 1988; Studia medyczne a etos zawodu lekarza, Akademia Medyczna, Kraków 1987.

7 Stefan Baley (1885-1952), polski psycholog. Należał do szkoły lwowsko-warszawskiej. Był kierownikiem Katedry Psychologii Wychowawczej na Uniwersytecie Warszawskim. Główne dzieła Baleya: Drogi samopoznania, Wiedza-Zawód-Kultura, Kraków 1947; Psychologia wychowawcza w zarysie, Państwowe Wydawnictwo Naukowe, Warszawa 1967; Wprowadzenie do psychologii społecznej, Państwowe Wydawnictwo Naukowe, Warszawa 1961.

8 Andrzej Szyszko-Bohusz ukończył pedagogikę na Uniwersytecie Jagiellońskim. Twórca pedagogiki holistycznej, która jest nauką interdyscyplinarną: obejmuje pedagogikę, filozofię i psychologię. Główne dzieło Szyszko-Bohusza: Pedagogika holistyczna, Zakład Narodowy im. Ossolińskich - Wydawnictwo, Wrocław 1989.

9 Tadeusz Kielanowski (1905-1992), polski lekarz i pomysłodawca Telefonu Zaufania. Główne dzieła Kielanowskiego: Rozmyślania o przemijaniu, Wiedza Powszechna, Warszawa 1980; Wybrane zagadnienia z etyki i deontologii lekarskiej, Państwowy Zakład Wydawnictw Lekarskich, Warszawa 1980; Odpowiedzialność uczonych: dylemat wspótczesnej nauki, Wiedza Powszechna, Warszawa 1970.

10 Antonii Kępiński (1918-1972), twórca psychiatrii aksjologicznej. Cenił humanitarne i dialogiczne podejście do pacjenta. Badał syndrom KZ, czyli stres pourazowy występujący u osób, które przeżyły obozy koncentracyjne. Twórca koncepcji metabolizmu informacyjnego oraz energetycznego. Główne dzieła Kępińskiego: Lęk, Wydawnictwo Literackie, Kraków 2004; Refleksje oświęcimskie, Wydawnictwo Literackie, Kraków 2005; Schizofrenia, Wydawnictwo Literackie, Kraków 2015.

11 Włodzimierz Sedlak (1911-1993), ksiądz i naukowiec. Stworzył elektromagnetyczną teorię życia, bioelektronikę. Główne dzieła Sedlaka: Wprowadzenie w bioelektronikę, Zakład Narodowy im. Ossolińskich - Wydawnictwo, Wrocław 1988; Życie jest świattem, Continuo, Radom 2004; Homo electronicus, Wydawnictwo Continuo, Radom 2005.

12 Henryk Skolimowski, polski filozof i twórca ekofilozofii. Główne dzieła Skolimowskiego: Filozofia żyjąca: eko-filozofia jako drzewo życia, przeł. J. Wojciechowski, „Pusty Obłok", Warszawa cop. 1993; Medytacje o nędzach cywilizacji technicznej i o blaskach życia ludzkiego, Odnowa, Londyn 1979; Nadzieja matka mądrych, Akapit Press, Łódź 1993.

13 Jerzy Grotowski (1933-1998) był reżyserem i znawcą teatru, a także pełnił funkcję dyrektora Teatru Laboratorium we Wrocławiu. 
dobnym tonie wypowiadała się Maria Grzegorzewska, twierdząc, że zdrowie psychiczne stanowi pewną zdolność do rozwoju i twórczej pracy nad samym sobą. Bardzo ważne w tym kontekście jest pojęcie wartości. Kępiński i twórczyni pedagogiki specjalnej jawnie wypowiadali się o aspekcie aksjologicznym człowieka, który wpływa na jakość relacji interpersonalnych, ale i na tożsamość indywidualnej osoby niezależnie od deficytów psychicznych i fizycznych ${ }^{14}$. Maria Grzywak-Kaczyńska również uważa, że interakcje z ludźmi są fundamentem wszelkiej działalności człowieka w świecie. Osobowość człowieka nie rozwija się jedynie dzięki samoświadomości, wewnętrznej autorefleksji, a poprzez pozytywne odniesienie do otaczających osób i samowychowanie ${ }^{15}$. Julian Aleksandrowicz sądzi, że zdrową osobowość cechuje odpowiedzialność i sumienie ekologiczne, dzięki któremu człowiek poszerza troskę i dojrzałość moralną. Stefan Baley zwraca się w stronę osobowości uspołecznionej, gdyż bez więzi społecznych psychika człowieka stanowi martwą i nienaturalną abstrakcję ${ }^{16}$. Autorka publikacji odnosi się również do koncepcji relaksacyjnej Andrzeja Szyszko-Bohusza. Pedagog ten jako zwolennik pedagogiki holistycznej, wychodzi z założenia, że higiena psychiczna rozwija się poprzez wprowadzenie racjonalnego relaksu, odpoczynku i odprężenia oraz zdystansowania wobec własnych niedoskonałości i pracy zawodowej. Codzienna relaksacja może doprowadzić do oczyszczenia umysłu z nadmiaru stresogennych elementów, a także wywołać spokój emocjonalno-duchowy. Jest to możliwie również w medycynie, gdy lekarze częściej będą traktować pacjentów przez pryzmat holistycznej całości, a nie jedynie w sposób fragmentaryczny, lecząc wyłącznie skutki, a nie przyczyny chorób. W związku z tym Tadeusz Kielanowski proponuje odnosić się do drugiego człowieka jak do niepodzielnej jedności psycho-fizycznej ${ }^{17}$. Zdaniem Antoniego Kępińskiego życie psychiczne człowieka nie jest oderwane od ciała i aspektu duchowego. Ukończył on studia medyczne, ale wdrażał w życie cechy psychiatrii humanistycznej. W koncepcji bioelektronicznej Włodzimierza Sedlaka dostrzegamy elementy integrujące psychikę i cielesność człowieka. Człowiek współczesny zamiast zwracać się w kierunku swojego wnętrza, wybiera uzewnętrznianie się, ignorując przy tym potrzeby ducha. Henryk Skolimowski proponuje dodanie do tych rozważań pojęcie świadomości ekologicznej, która opierałaby się na takich elementach, jak: postawa holistyczna, jakość relacji interpersonalnych, rewerencja (wgląd empatyczny i poszanowanie), postawa uczestnicząca,

14 A. Iwanicka-Maciura, Antropologia filozoficzna w ujęciu polskiej szkoły higieny psychicznej, s. 31-35.

15 Ibidem, s. 36.

16 Ibidem, s. 37-40.

17 Ibidem, s. 40-43. 
jako przeciwstawienie stechnicyzowanej egzystencji (która jest atomizująca, ilościowa, sekularystyczna, obiektywna, mechanistyczna, alienująca). Twórca Teatru Laboratorium Jerzy Grotowski podkreśla, że dzięki poznawaniu innych ludzi, w akcie spontanicznych zachowań, rodzi się samopoznanie, samodoświadczenie i samowiedza. Wówczas człowiek przestaje być taki „pokawałkowany” 18 .

Zasadnicze wydaje się również pojęcie wartości indywidualnych wprowadzone przez Annę Iwanicką-Maciurę, która na bazie poglądów wskazanych już badaczy analizuje takie oto pryncypia: ideały, rozwój wewnętrzny, poczucie więzi z ludzkością, empatia, perfekcjonizm i akceptacja siebie. Te pryncypia aksjologiczne stanowią części składowe zachowania pozytywnej, ale i dającej poczucie bezpieczeństwa higieny psychicznej. Najważniejszą wartością jest - moim zdaniem - akceptacja siebie, ponieważ jak podkreśla Malcolm Godwin: „Akceptacja jest pierwszym i jednocześnie ostatnim krokiem do odnalezienia siebie"19. Interesujące jest także nawiązanie do wartości społecznych i politycznych, które mają zostać sformułowane na gruncie higieny psychicznej. Iwanicka-Maciura opisuje zasadę holistyczną, która deprecjonuje fragmentaryczną wizję człowieka i jego więzi ze światem. Kładzie również nacisk na pacyfizm, czyli sprzeciwianie się działaniom wojennym, agresywnym i pełnym przemocy i jako przykład podaje przede wszystkim działania Mahatmy Gandhiego, który stosował się do zasady ahimsy (niestosowanie przemocy). Podrozdział publikacji zatytułowany Wzorce zawodów niesie za sobą istotne zadanie i rolę, jakim powinien sprostać dobry nauczyciel, pedagog i wychowawca. Konstruktywny i rozumiejący oraz autentyczny nauczyciel powinien mieć cechy psychoterapeuty (zdaniem Dąbrowskiego, Szyszko-Bohusza i Grzywak-Kaczyńskiej). Za kluczowe w tej monografii uznaję wprowadzenie podrozdziału Projekty reform społeczno-politycznych. Kazimierz Dąbrowski uważa, że charakter polskiej kultury ulega negatywnym przewartościowaniom. Destrukcyjne cechy polskiego charakteru przejawiają się głównie w akceptowaniu niekompetencji pracowników, w zachowaniach lekkomyślnych, warcholskich, w powierzchowności interakcji i klikowości, czyli działaniach w obrębie pewnej grupy społecznej hołdującej wspólnemu interesowi ${ }^{20}$. System nauczania należy przeformułować z edukacji kontenerowej na heurystyczna, o czym wspominał Julian Aleksandrowicz. Oznaczałoby to przejście z czystej faktografii na edukację sposobów rozwiązania problemów. Włodzimierz Sedlak rów-

18 Ibidem, s. 43-49.

19 M. Godwin, Kim jestem? 101 Dróg do odkrycia siebie, Warszawa 2001, s. 101-102, w: A. Iwanicka-Maciura, Antropologia filozoficzna w ujęciu polskiej szkoły higieny psychicznej, s. 146.

20 Ibidem, s. 187. 
nież zaznacza, że nowa edukacja powinna być powiązana z interdyscyplinarną wiedza, by tworzyć nowe syntezy ${ }^{21}$.

Warto przeczytać publikację Anny Iwanickiej-Maciury i przemyśleć treści w niej zawarte. Przytoczeni naukowcy i badacze mogą uświadomić czytelnika, że esencja interakcji społecznych, ale też politycznych wynika z moralnej akceptacji inności ludzi nas otaczających. Polska szkoła higieny psychicznej to nie tylko Kazimierz Dąbrowski z teorią dezintegracji, dzięki której człowiek ma możliwość wspinania się od niższych form rozwoju do tych wyższych i samoświadomych, choć droga ta jest przepełniona wzmożoną pobudliwością, nerwowościa, chaosem, lękiem, niestabilnością, brakiem integralności w obrębie struktur psychicznych.

„Opracowanie i wprowadzanie w życie (w wychowanie) zasad i metod obiektywizacji funkcji uczuciowych i popędowych oraz hierarchii wartości jest jednym z podstawowych warunków autentycznego wychowania człowieka"22.

Myśliciele z dziedzin psychologii, filozofii, pedagogiki i medycyny wprowadzają czytelnika w rzeczywistość, w której znajdują się skomplikowane, ale i zróżnicowane oraz pełne życzliwości zależności między pacjentem a lekarzem, między pedagogiem a uczniem, między osobą przychodzącą na terapię a psychoterapeutą. Warto zwrócić uwagę na to, że przytoczeni przeze mnie myśliciele charakteryzują się postawą rozumiejąca, współodczuwającą i zawieszającą bezpodstawne sądy moralne i wartościujące. Uważam, że zachowanie empatyczne, pragnienie wczuwania się $\mathrm{w}$ stany psycho-emocjonalne innych ludzi stanowi obecnie zasób deficytowy, albowiem niebagatelną cechą później nowoczesności jest stopniowy zanik wspólnotowości i więzi społecznych, co jest powodem stopniowego wyobcowania i powolnego „uśmiercania” dyspozycji odpowiadających za dialog międzyludzki i współistnienie. Dlatego tak istotne wydaje mi się dążenie do pielęgnacji konstruktywnego charakteru w człowieku i rozwijania cnót moralnych. Natasza Szutta stwierdza, że etyka cnót ${ }^{23}$ odzwierciedla się $\mathrm{w}$ człowieku w pewnych okolicznościach i wydarzeniach egzystencjalnych. Nie odnosi się do charakteru powinnościowego, tylko do sytuacyjnego, co nie wiąże się z relatywizmem etyczno-aksjologicznym i ze stwierdzeniem, że człowiek i jego środowisko zewnętrzne nie jest jednoznacznie zdefiniowane, a nieprzerwanie poddawane jest reinterpretacji i „hermeneutyzacji”.

Należy sięgnąć po tę publikację chociażby dlatego, że z jednej strony przedstawia poglądy myślicieli, którzy byli i nadal pozostają osobami

21 Ibidem, s. 189.

22 Ibidem, s. 220.

23 Zob. N. Szutta, Status współczesnej etyki cnót, „Diametros”, nr 1, wrzesień 2004, s. 70-84. 
o nietuzinkowym zmyśle moralnym, scalonej i konstruktywnej tożsamości i określonym systemie wartości, a z drugiej poprzez załączoną w aneksie biografię osób chorych autorka konfrontuje czytelnika z aktualnymi problemami osób z zaburzeniami i chorobami psychicznymi, a także egzystencjalnymi, których często dotyka ekskluzja społeczna. Zjawisko to powinno doprowadzić do sytuacji namysłu na indywidualnym zmysłem moralnym i wrażliwością społeczną.

Aleksandra Kondrat Uniwersytet Mikołaja Kopernika, Toruń e-mail: moskwa.ros@gmail.com 